\title{
Innovation in Stra. Tech. Man \\ (Strategy-Technology-Management) Terms
}

\author{
Charis Michael Vlados \\ Department of Economics, Democritus University of Thrace, Greece \\ School of Business, University of Nicosia, Cyprus \\ Fotios Katimertzopoulos \\ Department of Economics, Democritus University of Thrace \\ Panepistimioupoli Komotini, Greece \\ Ioannis Blatsos \\ Athens University of Economics and Business, Greece
}

Received: August 29, 2018 Accepted: December 28, 2018 Published: February 4, 2019

doi:10.5296/jebi.v5i2.13477 URL: http://dx.doi.org/10.5296/jebi.v5i2.3477

\begin{abstract}
The conventional neoclassic approach of the entrepreneurial economic development perceives innovation to a large extent restrictively and unproductively. In a parallel motion, the conventional Keynesian perspective proves to be as well insufficient to study the innovation dynamics evolutionary and dialectically.

On the contrary, toward a theoretical repositioning of the innovation studies, there are appearing new approaches that continue the evolutionary study of the capitalistic Firm's physiology that began in the mid- $20^{\text {th }}$ century.

This paper focuses especially on this theoretical redefinition to innovation dynamics. It tries to unfold a view of the Firm of physiological and evolutionary type, by highlighting a new synthesis of Strategy, Technology and Management (the 'Stra.Tech.Man' triangle) that represents the organic center of the produced innovation, inside all socioeconomic organisms.
\end{abstract}

Keywords: Innovation, firm theory, evolutionary economics, Stra.Tech.Man analysis

\section{Introduction}

The central importance of innovation dynamics, for any socio-economic organization of any kind - at any spatial or functional level of analysis - is progressively becoming indisputable 
in the literature of economics and management in the $21^{\text {st }}$ century (Brynjolfsson, \& McAfee, 2015; Carlino, \& Kerr, 2015; Gordon, 2017; Hall, Mairesse, \& Mohnen, 2010; OECD, 2014; OECD, 2015; OECD, 2016; Paunov, \& Guellec, 2017). However, the assimilation of a coherent view of innovation dynamics proves particularly difficult process in the practice of the majority of decision makers and socioeconomic actors. The traditional and conventional economic theory, not only of neoclassical but also of orthodox Keynesian inspiration and direction, it constantly fails to fully perceive the overall discipline of innovation (Colander, 2000; Colander, Holt, \& Rosser, 2004; Howson, 2001; Marshall, 1879; Marshall, 1890; Marshall, 1919; Rueff, 1947; Samuelson, 1951).

\subsection{Conventional Neoclassical Theory and The Innovation Dynamics}

In principle, the conventional neoclassic business and economic development theory examines the function of the market as a simple - and in fact an isolated from any broader socioeconomic system-resource allocation mechanism. For these theories, the demand functions interact with the supply functions in order to set prices, achieve and maintain a steady market equilibrium (Aspromourgos, 1986; Morgan, 2015).

In the absence, however, of any broader and more coherent socioeconomic perspective, the various 'players' within this system are most commonly regarded as static 'rational beings' - endowed with absolutely static and non-historical rationality and without any socioeconomic interconnection and/or influence (Walras, 1874). The capitalist enterprise is therefore considered here, in the vast majority of the relevant conventional theories, as a static 'black box' which exists to simply carry out an automatic transformation of economic inputs into outputs (Aoki, 1984; Arrow, 1974; Baudry, \& Tinel, 2003; Boyer, \& Durand, 1993; Coase, Gillis, \& Thiébault, 1987; Holmstrom, 1999; Williamson, 1991; Williamson, 1999; Williamson, 2000).

In particular, in neoclassical theory, the pace of technological change affects the pace of economic growth although is not affected respectively. That is, the reverse does not apply: The relationship appears strictly as one-way direction (Sollow, 1957).

So where does the technological change and progress stem from, according to this theoretical approach?

In the interpretative depth of this approach, technological change is ultimately determined simply by some 'luck'. In short, when a socio-economic system is fortunate, then technological change is being accelerated while, on the contrary, when there is less fortune, the pace of technological progress is slowing down — and, ultimately, there is nothing we can do to influence this pace, according to this theoretical approach. Innovation is always being triggered by independent exogenous variables and mechanisms and, therefore, the socioeconomic actors operating with consistent logical criteria can control the innovation system to a certain extent but cannot influence its pace and direction (O'sullivan, \& Sheffrin, 2003; Veblen, 1898; Veblen, 1900).

In overall, strategic, technological and organizational innovations are not explained by the neoclassical economic theory. They are simply seen as autonomous forces incorporated into 
the capital or knowledge, as prerequisites to manage the invested capital, organizational and human resources. At the industry level, these innovations are understood as choices made by businesses, in order to ensure 'temporary monopolist positions' to maximize their profits (Arena, \& Lazaric, 2003; Hodgson, 2002; Weinstein, \& Azoulay, 2000).

The way of thinking of this approach is rather simple: Since innovations disturb market equilibrium, then there needs to be some time until market mechanisms can react and restore a healthy balance between supply and demand. In this way, innovation becomes a temporary source of monopolistic power that provides some greater earnings than usual. In short, innovation remains, under this theoretical approach, as something unnatural but ultimately assimilated by the previous balance, while the socioeconomic context that surrounds it, remains stable and, by definition, inalienable (Machlup, 1959).

On a deeper sense, the neoclassical-oriented economic science traditionally finds it difficult to comprehend and interpretatively assimilate the dimension of knowledge. For conventional neoclassical economists, the key issue remains the use of existing knowledge, which is condensed simply on price information (Cohendet, \& Llerena, 1999; Foss, 1999; Hart, 1989; Holmstrom, \& Roberts, 1998; Prahalad, \& Hamel, 1990; Wernerfelt, 1984). According to the market mechanism in the model of full competition, all companies have the same standing knowledge that makes them possible to maximize their profits; each company does not create different knowledge (Argyris, 1977; Levitt, \& March, 1988; Loasby, 2009; Nonaka, \& Konno, 1998; Tarondeau, 1999). Thus, since the beginning of the neoclassical thinking, economists have been ignoring the enormous amount of inconsistent and explicit knowledge of economic subjects outside the price signals (Hailey, \& James, 2002; Rowley, \& Hartley, 2017). They have not dealt at all with knowledge creation and have not examined the business as a creator of knowledge.

\subsection{The conventional Keynesian tradition and innovation dynamics}

In a parallel view, the conventional Keynesian tradition does not appear to be more open interpretively to the study of innovation dynamics. Despite a clear divergence from the neoclassical perspective - especially in terms of an economic system achieving an automatic equilibrium - it also does not seem able to welcome the innovation discipline in a more complete and structured way (Coddington, 1976; Sweezy, 1946).

A key point in Keynes' analysis concerns, of course, the approach of private investment as an important determinant of the macroeconomic equilibrium of the system (Hayes, 2008). He clearly emphasizes in his writings that it is impossible to rationally calculate the future returns of new investments and stresses the importance of trust in the economy and the decisive role of the entrepreneurs' animal instinct. However, in his General Theory, Keynes (Keynes, 1936) neglects the investments as an engine of introducing faster and more efficiently new technologies that are, in fact, the direct expression of this entrepreneurial animal instinct.

As Freeman \& Soete (Freeman, Soete, \& Mothe, 1995) rightly point out: "In fact, in General Theory, Keynes retreated to positions that neglect technology when he introduced the widely 
artificial concept of a temporary fall in the marginal profitability of capital without correlating it with real changes in technologies and capital stocks ... For Keynesians, it was hardly important to determine what were the new technologies and the fast-growing industries".

\section{Focusing on the Evolutionary Nature of the Capitalist Enterprise}

If the economic thinking does not remove the conceptual and interpretive constraints and the analytical myopia of traditional economic logic, both of neoclassical and Keynesian origin, then a more complete and reliable perception of innovation dynamics that drive our modern world cannot be achieved.

And it becomes progressively understood that the modern economic and organizational thinking and science has a lot to gain from a theoretical refocusing, centered on the evolutionary dynamics of the capitalist enterprise (Alchian, 1953; Aoki, 2007; Augier, \& Teece, 2008; Chassagnon, 2011a; Chassagnon, \& Hollandts, 2014; Coriat, 1995; Coriat, \& Weinstein, 2010; Mäki, 2004).

\subsection{Critique of the Conventional Approach to Firm's Theory}

In the conventional model of economic theory, the concept of the capitalistic enterprise was built on the basis of some extremely simplistic and crude assumptions regarding the innovation dynamics.

However, especially since the 1960 s, many theoretical contributions have come out to make a consistent critique of this rigid, traditional and conventional neoclassical and Keynesian model of perception of the capitalist enterprise and its innovation dynamics. Their source is twofold: it stems from both Modern Organizational Theory and Modern Economic Science, under the Evolutionary and Institutional orientation (Dosi, 1995; Dosi, \& Winter, 2003; Favereau, 2011; Fehr, Hart, \& Zehnder, 2011; Foss, \& Ishikawa, 2007: Hart, \& Holmstrom, 2010; Hodgson, 2012; Lawson, 2012; Lewin, \& Phelan, 2000; Nooteboom, 2009; North, 1990; North, 2005).

In particular, more and more research contributions, specifically articulated in the thematic field of Firm's theory, have argued with numerous arguments that we must renegotiate and re-examine the evolutionary dynamics that the capitalist enterprise incorporates and activates (Archibald, 1971; Chandler, 1962; Chamberlin, 1933; Coase, 1988; Menard, 1994; Penrose, 1952). Progressively, on the orbit of these theoretical developments, it is becoming increasingly visible that the capitalist enterprise is at the same time:

An evolutionary structured socioeconomic organization (Baumol, 1959; Shackle, 1967; Simon, 1982; Sraffa, 1926), a historical institution (Baudry, \& Chassagnon, 2010; Chassagnon, 2010; Chassagnon, 2011b; Roberts, 2010), a complex and versatile system that constantly pursues the preservation and reproduction of the mechanisms of homeostasis and negative entropy that it possesses in 'chaotic conditions' (Arbib, \& Lecci, 1972; Ashby, 1961; Baker, \& Gollub, 1996; Forrester, 1980; Gulick, 2012; Harle, \& Jouanneault, 1984; Kautz, 
2011; Lesourne, 1978; Senge, 1993; Von Bertalanffy, 1973; Wiener, 1948) and, finally, a living organism with internal physiological determinations (Chassagnon, \& Vivel, 2013; Loasby, 2007; Penrose, 1952).

Under this new and evolutionary approach, the enterprise ceases to be considered as merely a passive acceptor of some changes that 'fall out of nowhere' and is finally perceived as one of the most critical - the most critical in fact - producer of fundamental changes that invade the reality experienced at all levels; through its-incessant and imperative for its survival-innovative action.

All the previous steps have progressively gained special importance and today they prove to be absolutely necessary on an interpretative level, as globalization has come out to make the outline of the capitalist venture even more fluid and its dynamics even more complex under the context of the reshaped 'New Global Economy' (Abélès, 2012; Acemoglu, Gancia, \& Ziliboti, 2015; Adda, 2012; Aghion, Boulanger, \& Cohen, 2011; Alfaro, \& Charlton, 2013; Altomonte, et al., 2016; Arkolakis, et al., 2013; Baldwin, 2012; Boyer, 2015; Cohen, 2011; Corm, 2010; Fontaine, Goulard, \& Bodman, 2010; Graz, 2013; Sapir, 2010).

\subsection{The Evolutionary Physiology of the Firm}

It is becoming progressively visible, in the relevant international literature, that the role of the entrepreneur - of entrepreneurship and innovation - as the most critical factor of action and overturn cannot be overlooked without very serious explanatory losses (Schreyögg, \& Kliesch - Eberl, 2007).

Under the perspective presented in this paper, at least four critical questions concerning the evolutionary existence of the business hold a central position (Cyert, \& March, 1963; Galbraith, 1967; Leibenstein, 1978): Who and how shapes the future path of the business (Strategy)? Who and how implements the function of acquiring, exploiting, and using of information, knowledge and tools (Technology)? Who and how manages the organization and coordination of production (Management)? Who and how synthesizes all the above dimensions (Synthesis of Strategy, Technology and Management-Stra.Tech.Man), the innovation processes within them, and creates, in general, new fields of action in capitalism?

In such analytical direction, recently, a very important research effort is trying to develop a coherent theory and narrative of economic development focused on innovation (Aghion, et al., 2005; Perez, 2003). The economics of innovation, therefore, attempt to respond to the fundamental problem concerning the overall growth of productivity and productive factors (total-factor productivity) (Scherer, \& Ross, 1990; Antonelli, 2003).

Innovation economists believe, in particular, that the most important element of the economic growth process in today's knowledge-intensive economy is not exhausted to the mere accumulation of capital, as the conventional economic thought supports, but to the innovation dynamics motivated by the appropriate institutional, technological and cognitive externalities, as the modern evolutionary economics supports (Abell, Felin, \& Foss, 2008; Becker, Lazaric, 2009; Bellone, Musso, Nesta, \& Quéré, 2008; Boulding, 1991; Cohen, 2007; D'Adderio, 2008; Silva, \& Teixeira, 2009; Witt, 2008). 


\section{Macrothink}

Development, in the perspective of evolutionary economics, is thus reflected as the ultimate product of innovative knowledge, and thus refers to the policies that facilitate business and innovation, technological diffusion and interactive relationships between cooperative enterprises, while at the same time explore the structural effects on the innovation systems that create, reproduce and extend to the innovative environments in which they operate (Algan, Cahuc, \& Shleifer, 2013; Chaney, 2016; Leromain, \& Orefice, 2014).

\section{The Concept of Innovation in the Stra.Tech.Man Approach}

But the principal question still remains unanswered: Which could be a different, an evolutionary and dialectical way of capturing the concept of business and its innovation dynamics by focusing on its particular evolutionary potential?

According to the Stra.Tech.Man approach, that advocated in this paper, the 'heart' of every living, real enterprise is and always being formed, in the innermost level of analysis, within the three fundamental structural spheres: Strategy, Technology and Management - spheres that already possesses and mobilizes. Within these fundamental functional spheres, each business compiles and reconsolidates its available potential (both material and intangible) for effective innovation that will allow to compete for survival and growth within its ever-evolving socioeconomic environment (see Figure 1).

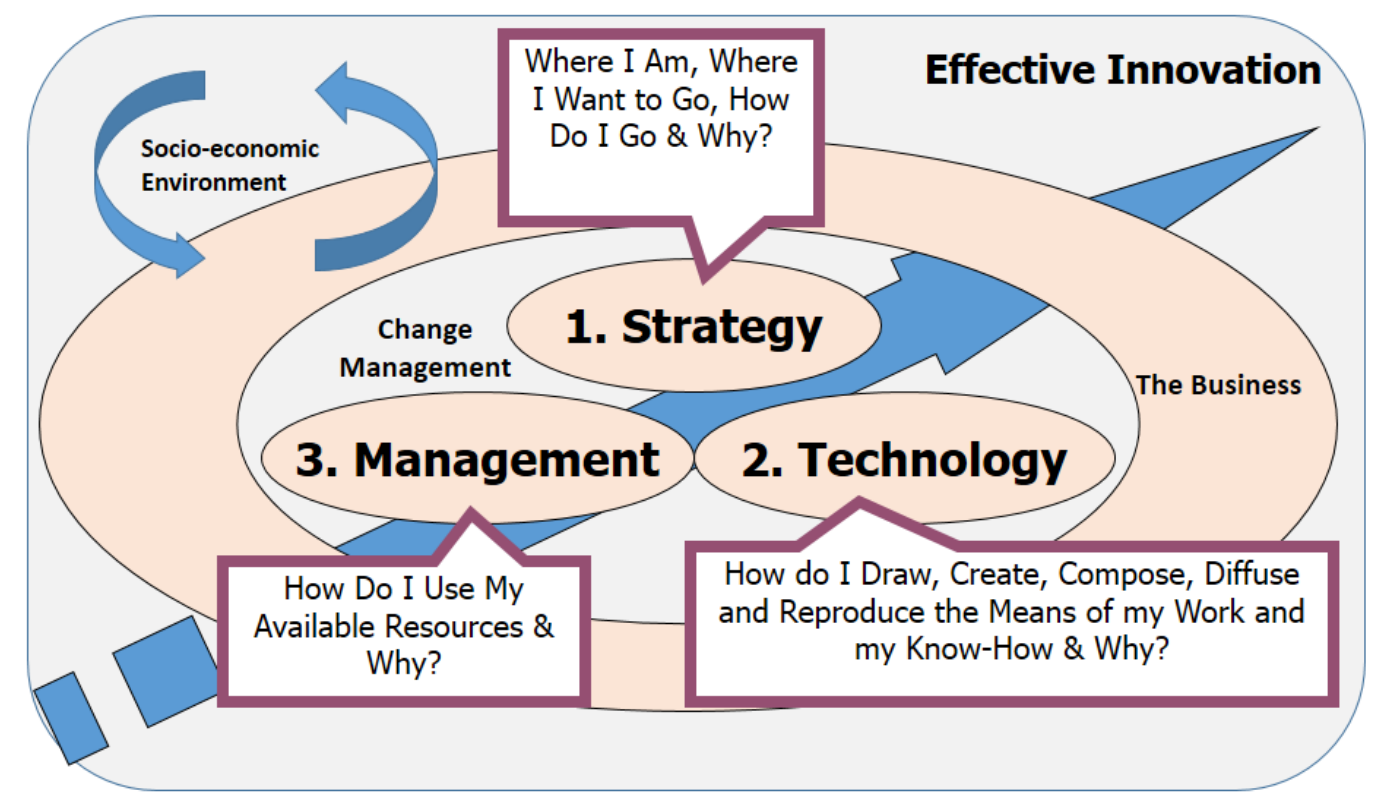

Figure 1. The evolutionary core of business.

Each sphere is being built, coexists and co-evolves with the rest, although with a distinct role. More specifically:

1. Strategy corresponds to "Where I Am, Where I Want to Go, How Do I Go \& Why?"

2. Technology to: "How Can I Create, Composite, Diffuse \& Reproduce the means of my Work and my Know-How \& Why?" 


\section{Macrothink}

3. And Management to: "How Do I Use My Available Resources \& Why?" (Spilanis \& Vlados, 1994; Vlados, 1992a; Vlados, 1992b; Vlados, 1996; Vlados, 2004; Vlados, 2005; Vlados, 2007; Vlados, 2012; Katimertzopoulos, \& Vlados, 2017; Vlados, Deniozos, \& Chatzinikolaou, 2018a; Vlados, Deniozos, \& Chatzinikolaou, 2018b; Vlados, Deniozos, Chatzinikolaou, \& Demertzis, 2018a; Vlados, Deniozos, Chatzinikolaou, \& Demertzis, 2018b; B $\lambda \alpha \dot{\delta} \delta o \varsigma, 2006$; B $\lambda \alpha ́ \delta o \varsigma, ~ 2007 ; ~ B \lambda \alpha ́ \delta o \zeta, ~ 2014 ;$ $\mathrm{B} \lambda \alpha \dot{\alpha} \delta$ o , 2016; B $\lambda \alpha ́ \delta$ os, 2017).

\subsection{The Stra.tech.man Dynamic Triangle}

These three-tier inner dimensions, in a continuous and dialectical way, determine the unique, specific and ever-evolving dynamic Stra.Tech.Man triangle. This evolutionary triangle uniquely characterizes every business, of every size, of every type, of every industry. Each business builds its own dynamic Stra.Tech.Man triangle, in a more or less explicit and systematical way, in order to effectively innovate and take a profit out of it: This is the core that always regulates, in the depth, its overall evolutionary course.

This triangle is, as such, in our view, the evolving, organic identity of every business. And under this understanding, the "biological type" and "natural selection" priorities are now placed in the central plan of the analysis of the evolutionary dynamics of Firm (Buenstorf, 2006; Festré, \& Garrouste, 2009; Hawley, 1950; Hodgson, 2010; Hodgson, \& Knudsen, 2007; Nelson, 2007; Prigogine, 1976; Wenting, 2009; Winter, 2006).

The dimensions of Strategy, Technology and Management are often inadequately perceived as inherently independent, autonomous and functionally separate from each other: this is defective and analytically disorienting. Instead, in reality, these dimensions are always in a close relationship of evolutionary synthesis and physiological co-adaptation - as the business is in fact a living and evolving organism. All three together, in their composition, define the Evolutionary Physiology of the Business.

In fact, the three dimensions necessarily coexist and are structurally co-defined nowadays, monitoring and restructuring at the same time the current dynamics of globalization (Artus, \& Virard, 2015; Balland, Suire, \& Vicente, 2013) (see Figure 2). 


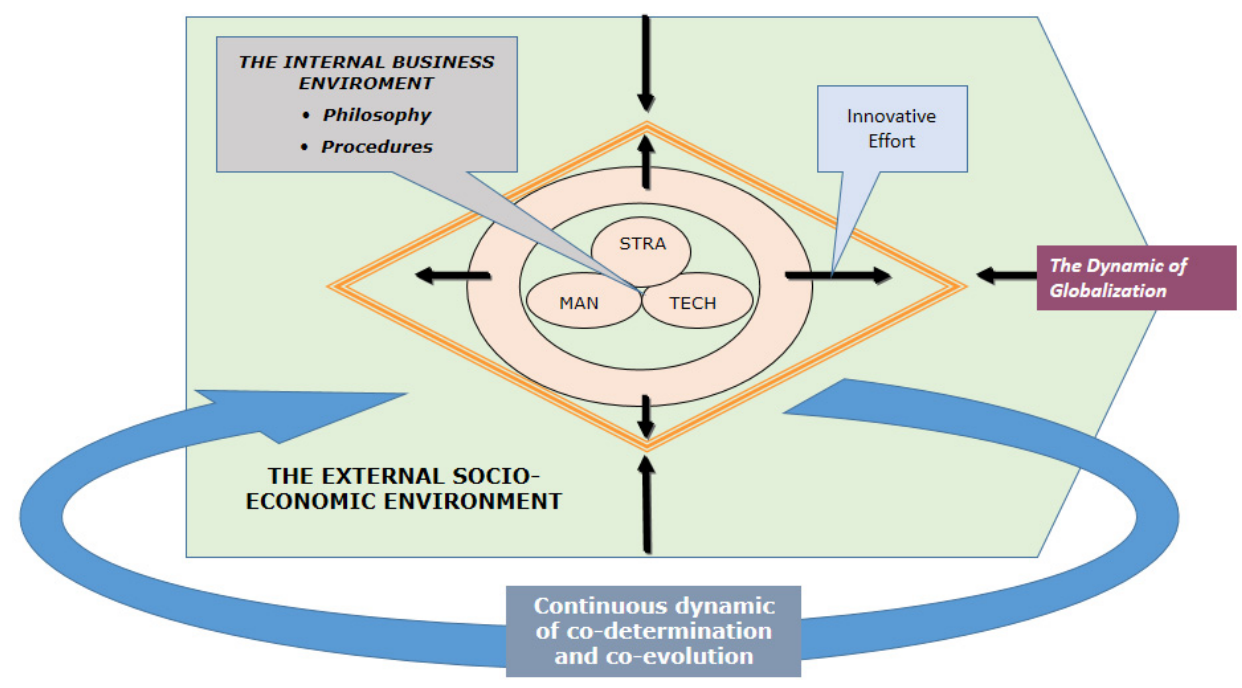

Figure 2. The business initiative as a dynamic synthesis of internal and external business environment through globalization

In practice, this dynamic Stra.Tech.Man triangle of the Business, operates as a systemic recipient, but also as a high-flux transformer, of the overall socioeconomic changes that are being produced-and produce respectively_globalization. The business' internal Stra.Tech.Man potential, structured on the continuous dialectical determination of Philosophy and Processes that characterize it, constructs its innovative effort as a survival and growth response to the environmental pressures it faces (see Figure 3).

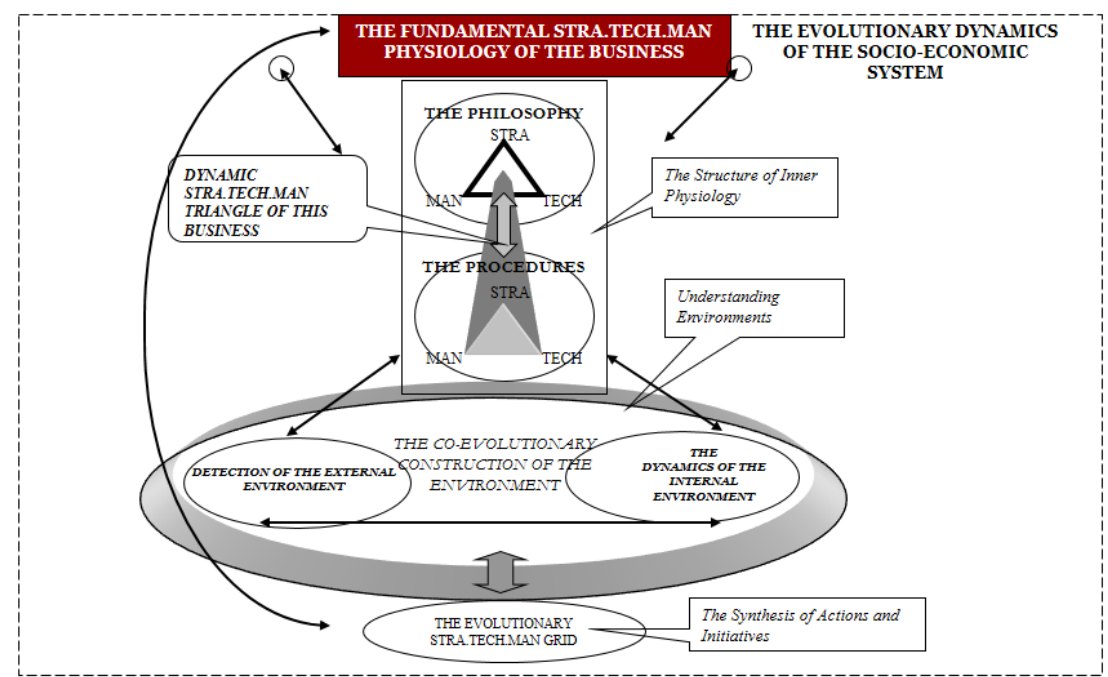

Figure 3. The evolutionary socioeconomic 'game' and the Stra.Tech.Man structure of a business.

In the light of this awareness, it becomes clear that businesses, like living organisms of all kinds, change and evolve to the limits of their local, national, and international environment, and actively affect the overall 'climate' of globalization through their innovative efforts ${ }^{[2]}$. 


\section{Macrothink}

\subsection{The Evolutionary Physiology of Firms}

The above described view of Stra.Tech.Man provides the possibility to make some theoretical clarifications:

I. Strategy, Technology and Business Management, although considered as independent dimensions in analytical terms, are inseparably interlocked and, inevitably, co-evolve in the evolutionary process. The competitive success of a business never concerns only one sphere individually, but all three together, in the specific way that their composition manages to provide effective responses to the constant changes of the environment.

II. Each business has its own 'biological' identity, which contains all the 'genetic information' that determines the possibility of its biological development. Specifically, the biological 'core' of any living and real business is always determined evolutionarily within these three fundamental and interconnected analytical spheres: strategy, technology and management, both in terms of inner philosophy and applied procedures (routines), are produced and reproduced by the business with the purpose of competitive survival and development, in the constantly evolving environment.

III. The physiological evolution of the business takes place, in practice, through dialectical conflicts, between:

- The Philosophy Stra.Tech.Man that characterizes it

- The Procedures Stra.Tech.Man that it uses (see Figure 4)

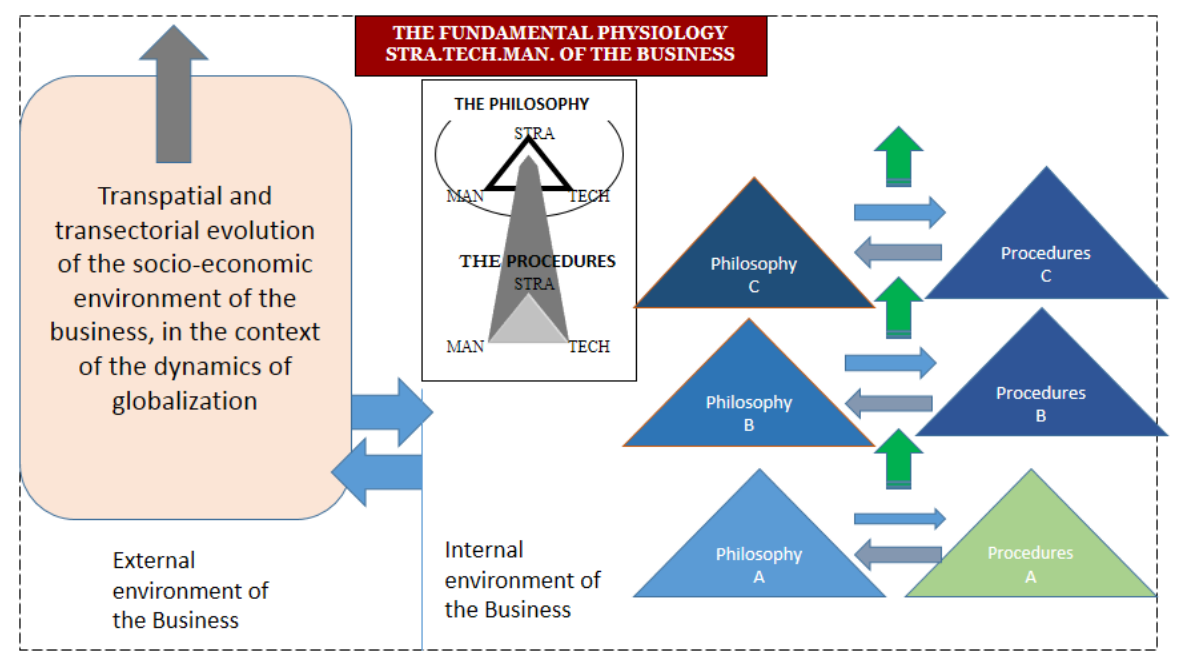

Figure 4. The Stra.Tech.Man physiological transformation of the business

IV. The business is a qualitative sum of its particular Stra.Tech.Man behavioral capabilities that define its kind. These capabilities are not formed by any unrealistic voluntarism or the mere 'desire' of its people. A business, more specifically, builds and transforms its distinct physiology as a synthesis of the applied business philosophy and business processes. It constructs the mechanisms of understanding its surroundings. It 
composes its initiatives. And it articulates its actions and evaluates them after the implementation.

V. Every successful business is led to the Stra.Tech.Man compositions and reconstructions which are materializing the specific in space and time business logic - the business rationality. Accordingly, this business physiology reproduces evolutionarily its own heterogeneity.

VI. All businesses, regardless of their size, like all living organisms, are understood as different natural species (they are different 'animals"): In this sense, the size of a business is not of central analytical significance in this view.

VII. The combined Stra.Tech.Man evolution of the internal and external business environment of the enterprise becomes the center of the overall process of innovation; it represents the 'natural selection' between the production systems and the overall socioeconomic development. The Stra.Tech.Man triangle is, in the long run, the perpetual engine of change for the business and for the surrounding environment (Vlados, 2004; B $\lambda \alpha$ ó $\delta$,

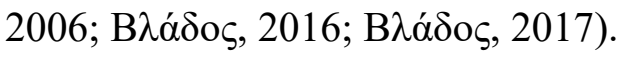

\subsection{The Stra.Tech.Man Triangle As the Innovative Engine of a Business}

According to this Stra.Tech.Man analysis, every innovation is always and necessarily characterized by the particular organic Stra.Tech.Man triangle. All innovations, constantly and necessarily, contain a part of Strategy, a part of Technology and a part of Management (Deming, 2000; Follet, 1977; Garratt, 1987; Juran, 1988; Masaaki, 1986; Nonaka, \& Takeuchi, 1995).

There are no innovations that can exist and be realized effectively without changing at the same time all three inner Stra.Tech.Man spheres of a socioeconomic organism. As a result, every kind of innovation is necessarily of Stra.Tech.Man reach.

Of course, innovation can be perceived to emerge only from one of the Stra.Tech.Man spheres, and be focused only in one functional area but, in the long run, every innovation requires always combined relocations and re-adjustments for the entire organization:

* For the strategy: And/or for the relationships with the customers, and/or for the markets, and/or for the value proposition, and/or for the product mix.

* For the technology: And/or for the tools, and/or for the working means, and/or for the particular know-how, and/or for the production process.

* For the management: And/or for the planning, and/or for the organization, and/or for the staffing, and/or for the management, and/or for the control, and/or for the coordination and communication.

And, in the background, every innovation bears internally a Stra.Tech.Man business 'gene' that has created that particular innovation.

\subsection{Innovation within the Operational Structure of the Business}




\section{Macrothink}

By studying the world of innovation nowadays, it becomes apparent that innovation can be born everywhere inside the business that interfaces with its external environment (customers, suppliers, or partners) (Brandenburger, \& Nalebuff, 1997; Hamel, \& Prahalad, 1994; Kim, \& Mauborgne, 2005; Moss Kanter, 2009; Nordstrom, \& Ridderstrale, 2007; Porter, 1991; Porter, 1996; Porter, \& Heppelmann, 2015; Schumpeter, 1934; Schumpeter, 1942) (see Figures 5 \& 6).

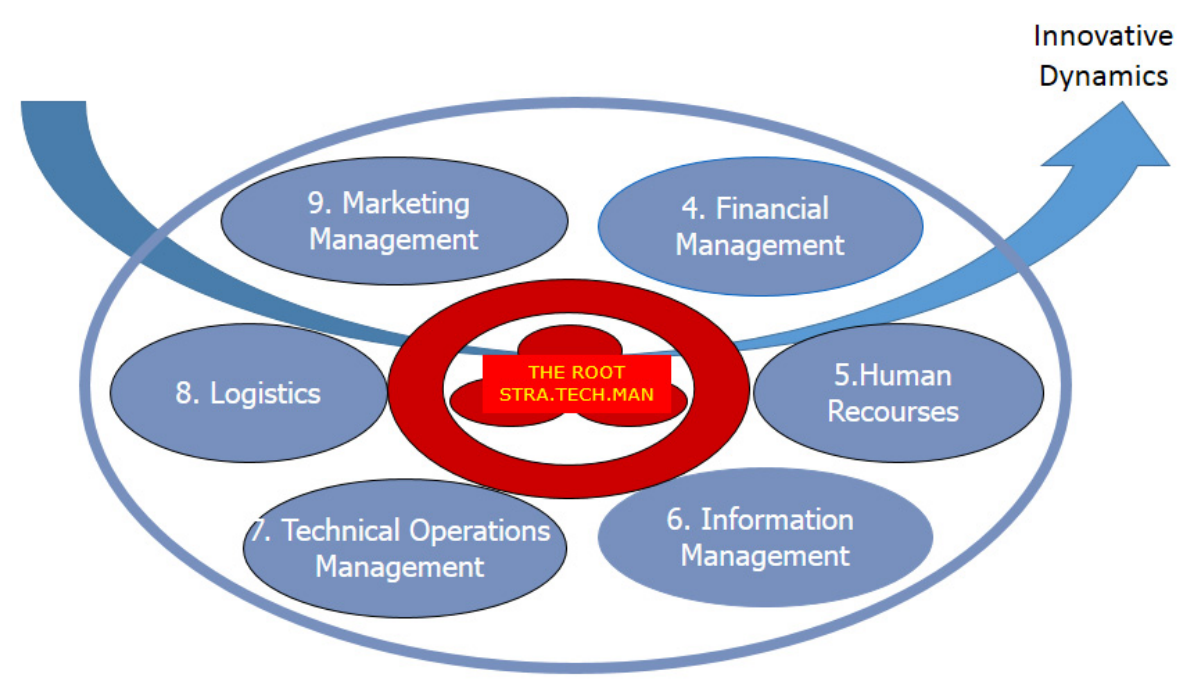

Figure 5. The core of business and innovative dynamics.

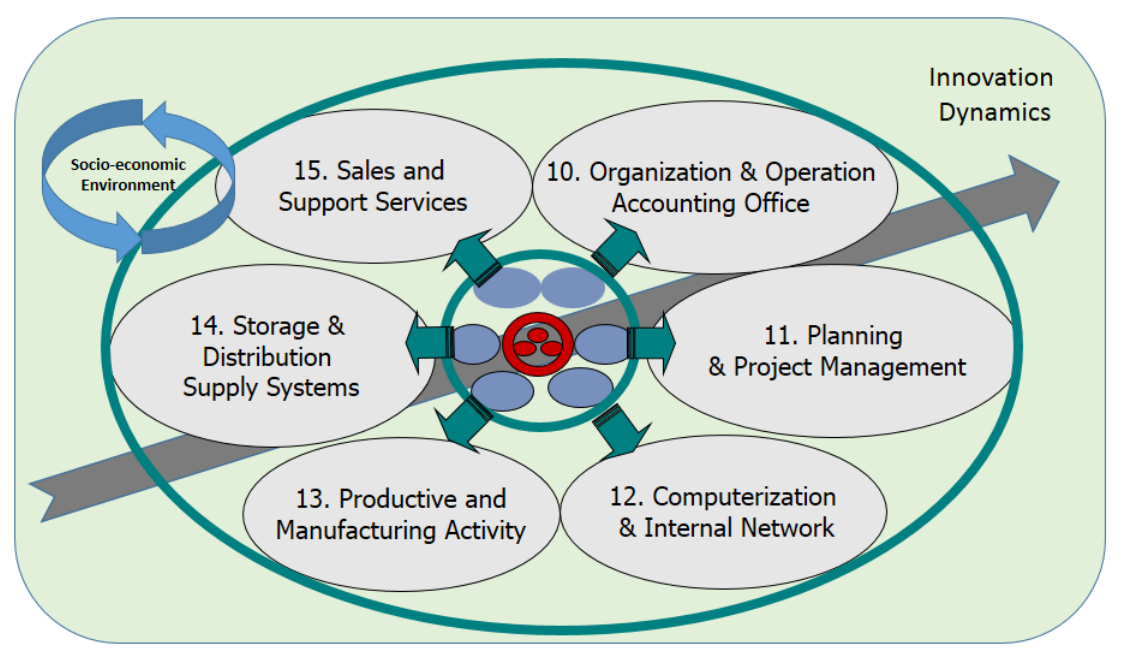

Figure 6. Contact points with the environment and innovation dynamics

Everything in the innovative effort works, both by necessity and by design, in combination: Organizational functions, environments and actions. Together they 'get out of comfort' and rebalance evolutionarily, endlessly, throughout the innovative game. This is necessary and inevitable. And all these lead to the continuation of the business itself in terms of the 


\section{Macrothink}

Stra.Tech.Man triangle.

Naturally, innovations can vary widely and may include many types of 'overturning' - all innovations do not have the same evolutionary dynamics and profitability. Whether they derive from an initiative coming from the 'base' (Hamel, 2000; Prahalad, 2004), the 'top' (Kotter, 1996) or the 'core body' of the organism, they always touch and affect the entire organism, on all sides.

Nowadays, by studding the empirical field, it becomes clear that a healthy and dynamic 'tree' (organization-business) should be able to produce many 'apples' (innovations), so that the increasingly competitive conditions of the future can be looked forward with optimism. It has been observed that, very often, many companies are wasting their innovative potential carelessly. Often, innovative applications emerging within organizations are ignored, neglected and spent pointlessly. How many good applications within some organizations, how many smart solutions, how many fertile initiatives, how many fruitful initiatives have not being hampered, jeopardized, and blocked? In this paper is estimated that modern innovative enterprise has to refuse, actively and systematically, this misuse. Any modern efficient business should deny this innovative waste. Instead it should collect, group and preserve its innovative initiatives in a way that they will be compiled, coordinated and fertilized. The authors of the present research believe that, in practice, every organization has to learn to look at the depth of innovation. It has to detect within the innovations the special features of Stra.Tech.Man they possess. It must analyze, deep down, their particular composition.

It must realize, first and foremost, that the emerging innovations are often 'organically relevant' to each other, whether these are born from this combination of Stra.Tech.Man functions or implemented in one such functional business area. And, very often, innovations accumulate in groups-like 'bunches': In practice an innovation gives birth to some other, more or less, relevant innovations (Gest, 1986) (see Figure 7).

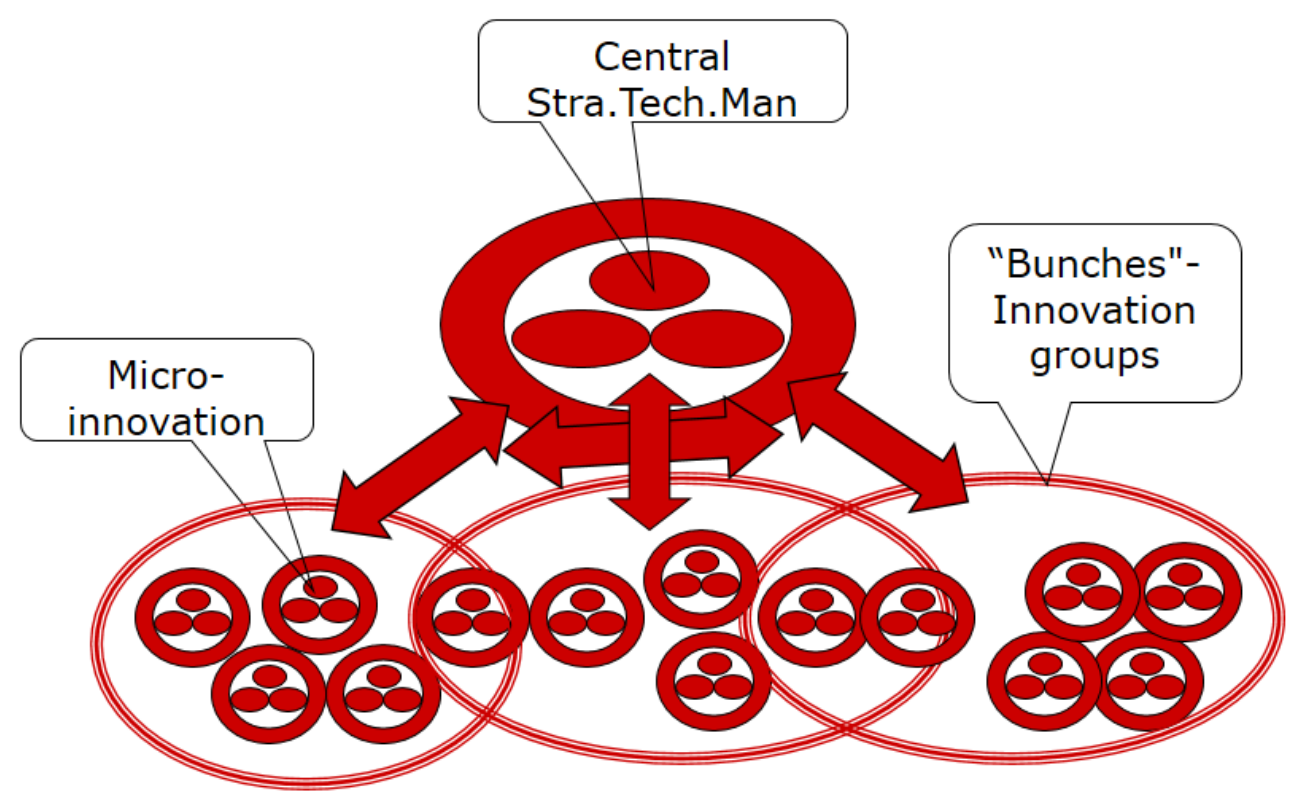




\section{Macrothink}

Figure 7. Central Stra.Tech.Man 'bunches'-Innovation groups and micro-innovation.

The central administration of each organization has to 'graft' the innovations of the organization with any additional components may be required in order to make them more effective; to become distinct and acquire a specific 'personality' within the competition. Ultimately an innovative business should seek to give a greater satisfaction to the customer and the market, either by providing a higher quality coverage of their needs, or by offering more attractive prices, or even both. In doing so, a new competitive dynamic for the organization is created.

Obviously, the most important aspect is how the business will manage these inherent structural changes so that it can cultivate, develop, preserve, diffuse and produce effective innovations; these innovative changes, ultimately, that would enhance the survival and development prospects, according to the specific in space and time external organizational environment (Covey, 1992; Duck, 1993; Elias, 2009; Jaques, 2017; Martin, 1993; Oreg, 2003).

And this realization is always on the basis of understanding the particular limits and prospects of the Stra.Tech.Man business physiology. Ultimately, in order for any to business survive it has to rebuild and transform the Stra.Tech.Man's physiology according to the specific external and internal environment. Keeping always in mind that Stra.Tech.Man defines the particular 'genetic code' that can be traced back to every 'organizational cell'-namely every initiative and action.

In parallel, it becomes apparent in our assumption that modern organizations should, on the one hand, try to organically understand the innovation process and, on the other hand, to assimilate an integrated biological perspective of their innovative effort. And they should progressively realize that nowadays innovation of the most advanced businesses is born from a deep dialectic fertilization and thinking. The era of unilateralism, of mere addition, of direct confrontation, and of the imposition of one sphere over another seems to have irreversibly been surpassed (see Figure 8). 


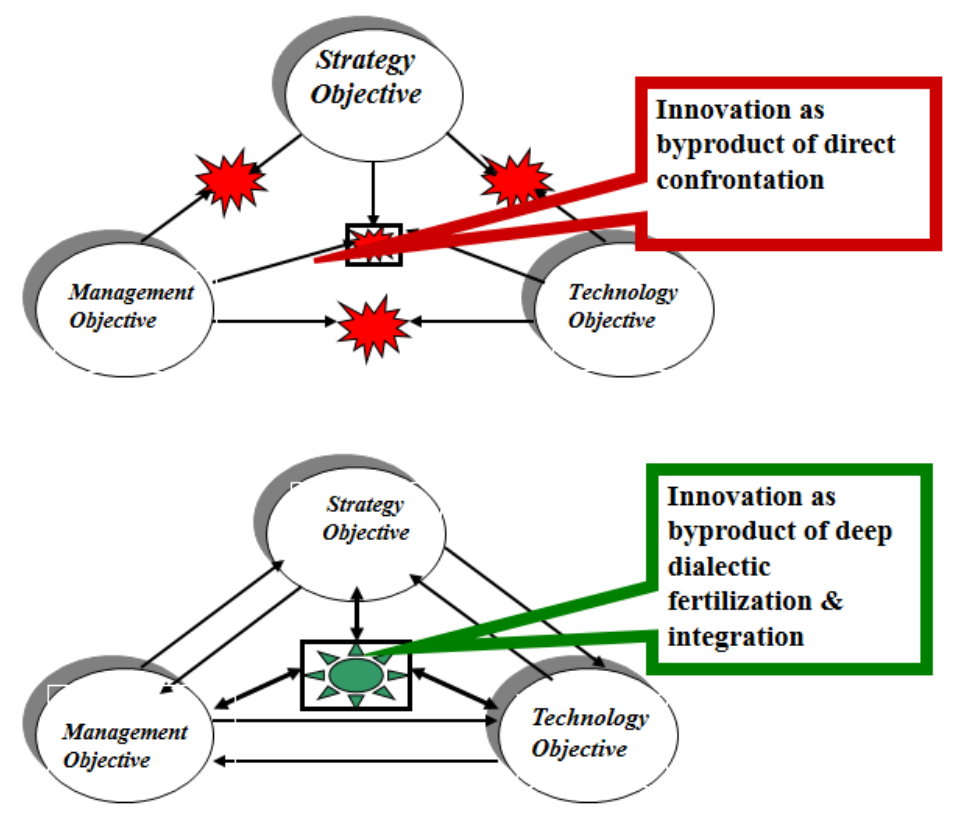

Figure 8. The Stra.Tech.Man logic: From the past to the future

In conclusion, in order for a synthesis of Stra.Tech.Man to prove effective, it has to transfigure the multifaceted internal potential of the organism (material and immaterial) according to the specific conditions set by the external environment. All innovations nowadays are always taking place within the global dynamics, that define, in turn, the competitiveness of all organizations - namely the ability to survive and develop.

\section{References}

Abélès, M. (2012). Anthropologie de la globalisation. Paris: Payot.

Abell, P., Felin, T., \& Foss, N. (2008). Building micro - foundations for the routines, capabilities, and performance links. Managerial and Decision Economics, 29(6), 489-502. https://doi.org/10.1002/mde.1413

Acemoglu, D., Gancia, G., \& Zilibotti, F. (2015). Offshoring and directed technical change. American Economic Journal: Macroeconomics, 7(3), 84-122. https://doi.org/10.1257/mac.20130302

Adda J., (2012). La mondialisation de l'économie. Paris: La Découverte.

Aghion, P., Bloom, N., Blundell, R., Griffith, R., \& Howitt, P. (2005). Competition and innovation: An inverted-U relationship. The Quarterly Journal of Economics, 120(2), 701-728.

Aghion, P., Boulanger, J., \& Cohen, E. (2011). Rethinking industrial policy. No. 2011/04. Brussels: Bruegel, 2011.

Alchian, A. A. (1953). Biological analogies in the theory of the firm: comment. The American Economic Review, 43(4), 600-603. 
Alfaro, L., \& Charlton, A. (2013). Growth and the Quality of Foreign Direct Investment. In Stiglitz, J. E., \& Lin, J. L. (Eds.), The Industrial Policy Revolution I (pp. 162-204). London: Palgrave Macmillan. https://doi.org/10.1057/9781137335173_12

Algan, Y., Cahuc, P., \& Shleifer, A. (2013). Teaching practices and social capital. American Economic Journal: Applied Economics, 5(3), 189-210. https://doi.org/10.1257/app.5.3.189

Altomonte, C., Bas, M., Bugamelli, M., Colantone, I., Fontagné, L., Forlani, E., \& Ottaviano, G. I. (2016). Measuring competitiveness in Europe: Resource allocation, granularity and trade. Bruegel Blueprint Series Volume XVIV, January 2016.

Antonelli, C. (2003). The economics of innovation, new technologies, and structural change. London: Routledge.

Aoki, M. (1984). The co-operative game theory of the firm. Oxford: Oxford University Press.

Aoki, M. (2007). Endogenizing institutions and institutional changes. Journal of Institutional Economics, 3(1), 1-31. https://doi.org/10.1017/S1744137406000531

Arbib, M. A., \& Lecci, A. (1972). The metaphorical brain: Introduction to cybernetics as artificial intelligence and brain theory. John Wiley \& Sons Inc.

Archibald, G. C. (ed.) (1971). The theory of the firm. Harmondsworth: Penguin Books.

Arena, R., \& Lazaric, N. (2003). La théorie évolutionniste du changement économique de Nelson et Winter. Revue économique, 54(2), 329-354. https://doi.org/10.3917/reco.542.0329

Argyris, C. (1977). Organizational learning and management information systems. Accounting. Organizations and Society, 2(2), 113-123. https://doi.org/10.1016/0361-3682(77)90028-9

Arkolakis, C., Ramondo, N., Rodríguez-Clare, A., \& Yeaple, S. (2013). Innovation and production in the global economy (No. w18972). National Bureau of Economic Research. https://doi.org/10.3386/w18972

Arrow, K. J. (1974). The limits of organization. New York: WW Norton \& Company.

Artus, P., \& Virard, M. P. (2015). Croissance zéro, comment éviter le chaos? Paris: Fayard.

Ashby, W. R. (1961). An introduction to cybernetics. Chapman \& Hall Ltd.

Aspromourgos, T. (1986). On the origins of the term 'neoclassical'. Cambridge Journal of Economics, 10(3), 265-270. https://doi.org/10.1093/oxfordjournals.cje.a034999

Augier, M., \& Teece, D. J. (2008). Strategy as evolution with design: The foundations of dynamic capabilities and the role of managers in the economic system. Organization studies, 29(8-9), 1187-1208. https://doi.org/10.1177/0170840608094776

Baker, G. L., \& Gollub, J. P. (1996). Chaotic dynamics. Cambridge: Cambridge University Press. https://doi.org/10.1017/CBO9781139170864

Baldwin, R. E. (2012). Global supply chains: why they emerged, why they matter, and where 
they are going. In Elms, D. K., \& Low, P. (Eds.), Global Value Chains in a Changing World (pp. 13-60). Lausanne: World Trade Organization Publications.

Balland, P. A., Suire, R., \& Vicente, J. (2013). Structural and geographical patterns of knowledge networks in emerging technological standards: Evidence from the European GNSS industry. Economics of Innovation and New Technology, 22(1), 47-72. https://doi.org/10.1080/10438599.2012.699773

Baudry, B., \& Chassagnon, V. (2010). The close relation between organization theory and Oliver Williamson's transaction cost economics: A theory of the firm perspective. Journal of Institutional Economics, 6(4), 477-503. https://oi.org/10.1017/S1744137410000147

Baudry, B., \& Tinel, B. (2003). Une analyse théorique des fondements et du fonctionnement de la relation d'autorité intrafirme. Revue économique, 54(2), 229-251.

Baumol W. J. (1959). Business behaviour, value and growth. London: Macmillan.

Becker, M. C., \& Lazaric, N. (Eds.). (2009). Organizational routines: Advancing empirical research. Cheltenham: Edward Elgar Publishing. https://doi.org/10.4337/9781848447240

Bellone, F., Musso, P., Nesta, L., \& Quéré, M. (2008). Market selection along the firm life cycle. Industrial and Corporate Change, 17(4), 753-777. https://doi.org/10.1093/icc/dtn025

Boulding, K. E. (1991). What is evolutionary economics? Journal of Evolutionary economics, 1(1), 9-17. https://doi.org/10.1007/BF01202334

Boyer, R. \& Durand, J.-P. (1993). L'après-fordisme. Paris: Syros.

Boyer, R. (2015). Économie politique des capitalismes. Théorie de la régulation et des crises. Paris: La Découverte.

Brandenburger, A. M., Nalebuff, B. J. (1997). Co-opetion. Currency Doubleday.

Brynjolfsson, E., \& McAfee, A. (2015). Le deuxième âge de la machine: Travail et prospérité à l'heure de la révolution technologique. Paris: Odile Jacob.

Buenstorf, G. (2006). How useful is generalized Darwinism as a framework to study competition and industrial evolution? Journal of Evolutionary Economics, 16(5), 511-527. https://doi.org/10.1007/s00191-006-0035-3

Carlino, G., \& Kerr, W. R. (2015). Agglomeration and innovation. In Handbook of regional and urban economics (Vol. 5, pp. 349-404). Elsevier. https://doi.org/10.1016/B978-0-444-59517-1.00006-4

Chamberlin, E. H. (1933). The theory of monopolistic competition. Cambridge, MA: Harvard University Press.

Chandler, A. D. (1962). Strategy and structure: Chapters in the history of the industrial enterprise. Cambridge, MA: MIT press.

Chaney, T. (2016). Networks in international trade. In Bramoullé, Y., Galleoti, A., \& Rogers, 


\section{Macrothink}

Journal of Entrepreneurship and Business Innovation

ISSN 2332-8851

2018, Vol. 5, No. 2

B. (Eds.), The Oxford Handbook of the Economics of Networks (pp. 754-775). Oxford: Oxford University Press.

Chassagnon, V. (2010). Jalons pour une théorie de la firme comme entité fondée sur le pouvoir: le gouvernement interne et externe des firmes modernes (Doctoral dissertation, Lyon 2).

Chassagnon, V. (2011a). The law and economics of the modern firm: A new governance structure of power relationships. Revue d'économie industrielle, (2), 25-50. https://doi.org/10.4000/rei.4983

Chassagnon, V. (2011b). Organisation et institution: Vers une socioéconomie de la firme?. International Review of Sociology, 21(3), 447-468. https://doi.org/10.1080/03906701.2011.625651

Chassagnon, V., \& Hollandts, X. (2014). Who are the owners of the firm: shareholders, employees or no one?. Journal of Institutional Economics, 10(1), 47-69. https://doi.org/10.1017/S1744137413000301

Chassagnon, V., \& Vivel, C. (2013). Frank H. Knight and Ronald H. Coase on the nature of the capitalist firm: An analysis of their seminal contributions (1921-1937). History of Economic Ideas, 21(2), 29-52.

Coase, R. H. (1988). The firm, the market and the law. Chicago: Chicago University Press.

Coase, R. H., Gillis, X., \& Thiébault, C. (1987). La nature de la firme. Revue française d'économie, 2(1), 133-163. https://doi.org/10.3406/rfeco.1987.1132

Coddington, A. (1976). Keynesian economics: the search for first principles. Journal of Economic Literature, 14(4), 1258-1273.

Cohen, D., (2011). La mondialisation et ses ennemis. Paris: Pluriel.

Cohen, M. D. (2007). Reading Dewey: Reflections on the study of routine. Organization Studies, 28(5), 773-786. https://doi.org/10.1177/0170840606077620

Cohendet, P., \& Llerena, P. (1999). La conception de la firme comme processeur de connaissances. Revue d'économie industrielle, 88(1), 211-235. https://doi.org/10.3406/rei.1999.1751

Colander, D. (2000). The death of neoclassical economics. Journal of the history of Economic Thought, 22(2), 127-143. https://doi.org/10.1080/10427710050025330

Colander, D., Holt, R., \& Rosser Jr, B. (2004). The changing face of mainstream economics. Review of Political Economy, 16(4), 485-499. https://doi.org/10.1080/0953825042000256702

Coriat, B. (1995). Variety, routines and networks: The metamorphosis of Fordist firms. Industrial and Corporate Change, 4(1), 205-227. https://doi.org/10.1093/icc/4.1.205

Coriat, B., \& Weinstein, O. (2010). Les théories de la firme entre "contrats" et "compétences". Une revue critique des développements contemporains. Revue d'économie industrielle, 
(129-130), 57-86. https://doi.org/10.4000/rei.4142

Corm, G., (2010). Le nouveau gouvernement du monde. Paris: La Découverte.

Covey, S. R. (1992). Principle centered leadership. New York: Simon and Schuster.

Cyert, R. M., \& March, J. G. (1963). A behavioural theory of the firm. Englewood Cliffs: Prentice Hall.

D'Adderio, L. (2008). The performativity of routines: Theorising the influence of artefacts and distributed agencies on routines dynamics. Research Policy, 37(5), 769-789. https://doi.org/10.1016/j.respol.2007.12.012

Deming, W. E. (2000). The new economics: For industry, government, education. MIT press.

Dosi, G. (1995). Hierarchies, markets and power: some foundational issues on the nature of contemporary economic organizations. Industrial and Corporate Change, 4(1), 1-19. https://doi.org/10.1093/icc/4.1.1

Dosi, G., \& Winter, S. G. (2003). Interprétation évolutionniste du changement économique. Revue économique, 54(2), 385-406. https://doi.org/10.3917/reco.542.0385

Duck, J. D. (1993). Managing change: The art of balancing. Harvard Business Review.

Elias, S. M. (2009). Employee commitment in times of change: Assessing the importance of attitudes toward organizational change. Journal of Management, 35(1), 37-55. https://doi.org/10.1177/0149206307308910

Favereau, O. (2011). New institutional economics versus economics of conventions: the difference between bounded rationality and... bounded rationality. Economic Sociology, the European Electronic Newsletter, 13(1), 22-27.

Fehr, E., Hart, O., \& Zehnder, C. (2011). Contracts as reference points: Experimental evidence. American Economic Review, 101(2), 493-525. https://doi.org/10.1257/aer.101.2.493

Festré, A., \& Garrouste, P. (2009). The economic analysis of social norms: A reappraisal of Hayek's legacy. The Review of Austrian Economics, 22(3), 259-279. https://doi.org/10.1007/s11138-009-0083-7

Follett, M. P. (1977). Dynamic administration: the collected papers of Mary Parker Follett. Buccaneer Books.

Fontaine F., Goulard, S., Bodman, B. (2010). La mondialisation. Paris: First Éditions.

Forrester, J. W. (1980). Principes des systèmes. Paris: PUL/CERG.

Foss, N. J. (1999). The use of knowledge in firms. Journal of Institutional and Theoretical Economics, 155(3), 458-486.

Foss, N. J., \& Ishikawa, I. (2007). Towards a dynamic resource-based view: Insights from Austrian capital and entrepreneurship theory. Organization Studies, 28(5), 749-772. https://doi.org/10.1177/0170840607072546 


\section{Macrothink}

Journal of Entrepreneurship and Business Innovation

ISSN 2332-8851

2018, Vol. 5, No. 2

Freeman, C., Soete, L., \& Mothe, J. D. L. (1995). Work for all or mass unemployment: Computerized technical change into the 21st century. Science and Public Policy, 22(6), 421-422.

Galbraith, J. K (1967). The new industrial state. Princeton University Press.

Garratt, B. (1987). The learning organization. London: Fontana.

Gest (1986). Grappes technologiques. Les nouvelles stratégies d'entreprise. Paris: McGraw-Hill.

Gordon, R. J. (2017). The rise and fall of American growth: The US standard of living since the civil war. Princeton University Press. https://doi.org/10.1515/9781400888955

Graz J.-C., (2013). La gouvernance de la mondialisation. Paris: La Découverte.

Gulick, D. (2012). Encounters with chaos and fractals (2nd edition). Chapman and Hall/CRC.

Hailey, J., \& James, R. (2002). Learning leaders: The key to learning organisations. Development in Practice, 12(3-4), 398-408. https://doi.org/10.1080/0961450220149753

Hall, B. H., Mairesse, J., \& Mohnen, P. (2010). Measuring the Returns to R\&D. In Hall, B., \& Rosenberg, N. (eds.). Handbook of the Economics of Innovation (Vol. 2, pp. 1033-1082). North-Holland. https://doi.org/10.1016/S0169-7218(10)02008-3

Hamel, G., \& Prahalad, C. K. (1994). Competing for the future. Boston, MA: Harvard Business School Press.

Hamel, G. (2000). Leading the revolution. New York: Penguin Books.

Harle, E., \& Jouanneault. D. (1984). L'entreprise en tant que système. Paris: PUL.

Hart, O. (1989). An economist's perspective on the theory of the firm. Columbia Law Review, 89(7), 1757-1774. https://doi.org/10.2307/1122818

Hart, O., \& Holmstrom, B. (2010). A theory of firm scope. The Quarterly Journal of Economics, 125(2), 483-513. https://doi.org/10.1162/qjec.2010.125.2.483

Hawley, A. (1950). Human ecology: A theory of community structure. New York: Ronald Press.

Hayes, M. (2008). The Economics of Keynes: A new guide to the General Theory. Cheltenham UK and Northampton US: Edward Elgar Publishing.

Hodgson, G. M. (2002). The legal nature of the firm and the myth of the firm-market hybrid. International Journal of the Economics of Business, 9(1), 37-60. https://doi.org/10.1080/13571510110102967

Hodgson, G. M. (2010). Darwinian coevolution of organizations and the environment. Ecological Economics, 69(4), 700-706. https://doi.org/10.1016/j.ecolecon.2008.06.016 


\section{Macrothink}

Journal of Entrepreneurship and Business Innovation

ISSN 2332-8851

2018, Vol. 5, No. 2

Hodgson, G. M. (2012). From pleasure machines to moral communities: An evolutionary economics without homo economicus. Chicago: University of Chicago Press. https://doi.org/10.7208/chicago/9780226922737.001.0001

Hodgson, G. M., \& Knudsen, T. (2007). Evolutionary theorizing beyond Lamarckism: a reply to Richard Nelson. Journal of Evolutionary Economics, 17(3), 353-359. https://doi.org/10.1007/s00191-007-0062-8

Holmstrom, B. (1999). The firm as a subeconomy. Journal of Law, Economics, and organization, 15(1), 74-102. https://doi.org/10.1093/jleo/15.1.74

Holmstrom, B., \& Roberts, J. (1998). The boundaries of the firm revisited. Journal of Economic perspectives, 12(4), 73-94. https://doi.org/10.1257/jep.12.4.73

Howson, S. (2001). Why didn't Hayek review Keynes's general theory? A partial answer. History of Political Economy, 33(2), 369-374. https://doi.org/10.1215/00182702-33-2-369

Jaques, E. (2017). Requisite organization: A total system for effective managerial organization and managerial leadership for the 21 st century. Routledge. https://doi.org/10.4324/9781315088846

Juran, J. (1988). Juran on planning for quality. New York: The Free Press.

Katimertzopoulos, F., \& Vlados, C. M. (2017). Local support mechanisms for entrepreneurship: The approach of local development and innovation institutions. International Journal of Business and Economic Sciences Applied Research, 10(1), 30-41. https://doi.org/10.25103/ijbesar.101.04

Kautz, R. (2011). Chaos: The science of predictable random motion. Oxford: Oxford University Press.

Keynes, J. M. (1936). The general theory of employment, interest and money. London: Macmillan.

Kim, W. C., \& Mauborgne, R. (2005) Blue ocean strategy: How to create uncontested market space and make competition irrelevant. Boston, MA: Harvard Business Review Press

Kotter, J. P. (1996). Leading change. Harvard Business School Press

Lawson, T. (2012). Ontology and the study of social reality: Emergence, organisation, community, power, social relations, corporations, artefacts and money. Cambridge Journal of Economics, 36(2), 345-385. https://doi.org/10.1093/cje/ber050

Leibenstein, H. (1978). General X-Efficiency theory and economic development. Oxford: Oxford University Press.

Leromain, E., \& Orefice, G. (2014). New revealed comparative advantage index: Dataset and empirical distribution. International Economics, 139, 48-70. https://doi.org/10.1016/j.inteco.2014.03.003

Lesourne J. (1978). La théorie des systèmes et la théorie économique. Economie Appliquée, 
31(3-4), 319-336.

Levitt, B., \& March, J. G. (1988). Organizational learning. Annual Review of Sociology, 14(1), 319-338. https://doi.org/10.1146/annurev.so.14.080188.001535

Lewin, P., \& Phelan, S. E. (2000). An Austrian theory of the firm. The Review of Austrian Economics, 13(1), 59-79. https://doi.org/10.1023/A:1007854129748

Loasby, B. J. (2007). A cognitive perspective on entrepreneurship and the firm. Journal of Management Studies, 44(7), 1078-1106. https://doi.org/10.1111/j.1467-6486.2007.00729.x

Loasby, B. J. (2009). Knowledge, coordination and the firm: Historical perspectives. The European Journal of the History of Economic Thought, 16(4), 539-558. https://doi.org/10.1080/09672560903201227

Machlup, F. (1959). Statics and dynamics: Kaleidoscopic words. Southern Economic Journal, 91-110. https://doi.org/10.2307/1055009

Mäki, U. (2004). Theoretical isolation and explanatory progress: transaction cost economics and the dynamics of dispute. Cambridge Journal of Economics, 28(3), 319-346. https://doi.org/10.1093/cje/28.3.319

Marshall, A. (1879). The pure theory of domestic values. London: London School of Economics and Political Science.

Marshall, A. (1890). Principles of economics (8th ed.). London: Macmillan.

Marshall, A. (1919). Industry and trade. London: Macmillan.

Martin, L. (1993). Changing the mind of the corporation. Harvard Business Review.

Masaaki, I. (1986). Kaizen: The key to Japan's competitive success. New York: MacGraw-Hill.

Menard, C. (1994). L'Economie des organisations. Paris: La Decouverte.

Morgan, J. (Ed.). (2015). What is neoclassical economics? Debating the origins, meaning and significance. London: Routledge.

Moss Kanter, R. (2009) Super Corp: How vanguard companies create innovation, profits, growth, and social good. Crown Business.

Nelson, R. R. (2007). Comment on: Dismantling Lamarckism: why descriptions of socio-economic evolution as Lamarckian are misleading, by Hodgson and Knudsen. Journal of Evolutionary Economics, 17(3), 349-352. https://doi.org/10.1007/s00191-007-0061-9

Nonaka, I., \& Takeuchi, H. (1995). The knowledge-creating company. New York: Oxford University Press.

Nonaka, I., \& Konno, N. (1998). The concept of "ba": Building a foundation for knowledge creation. California Management Review, 40(3), 40-54. https://doi.org/10.2307/41165942 


\section{Macrothink Institute $^{\mathrm{TM}}$}

Nooteboom, B. (2009). A cognitive theory of the firm: Learning, governance and dynamic capabilities. Cheltenham: Edward Elgar Publishing. https://doi.org/10.4337/9781848447424

Nordstrom, K., \& Ridderstrale, J. (2007) Funky Business Forever: How to enjoy capitalism. Pearson Education Canada.

North, D. C. (1990). Institutions, institutional change, and economic performance. Cambridge: Cambridge University Press. https://doi.org/10.1017/CBO9780511808678

North, D. C. (2005). Understanding the process of economic change. Princeton: Princeton University Press. https://doi.org/10.1515/9781400829484

OECD (2014). New sources of growth: Knowledge-based capital. Paris.

OECD (2015). Manuel de Frascatti. Paris.

OECD (2016). Science, technology and innovation outlook. Paris

Oreg, S. (2003). Resistance to change: Developing an individual differences measure. Journal of Applied Psychology, 88(4), 680. https://doi.org/10.1037/0021-9010.88.4.680

O'sullivan, A., \& Sheffrin, S. M. (2003). Economics: Principles in action. New Jersey: Pearson Prentice Hall.

Paunov, C., \& Guellec, D. (2017). Digital innovation and the distribution of income. In Corrado C., Miranda J., Haskel J. et Sichel D. (eds). Measuring and accounting for innovation in the 21st century. NBER, Book Series in Income and Wealth.

Penrose, E. T. (1952). Biological analogies in the theory of the firm. The American Economic Review, 42(5), 804-819.

Perez, C. (2003). Technological revolutions and financial capital. Cheltenham: Edward Elgar Publishing.

Porter, M. E. (1991). Towards a dynamic theory of strategy. Strategic management journal, 12(S2), 95-117. https://doi.org/10.1002/smj.4250121008

Porter, M. E. (1996). What is strategy?. Harvard Business Review, 61-78.

Porter, M. E., \& Heppelmann, J. E. (2015). How smart, connected products are transforming companies. Harvard Business Review, 93(10), 96-114.

Prahalad, C. K. (2004). The future of competition: Co-creating unique value. Harvard Business School Press

Prahalad, C. K., \& Hamel, G. (1990). The core competence of the corporation. Harvard Business Review, 3, 79-91.

Prigogine, I. (1976). Games of chance and necessity. Nature, 262(5571), 823-824. https://doi.org/10.1038/262823a0

Roberts, J. (2010). Designing incentives in organizations. Journal of Institutional Economics, 
6(1), 125-132. https://doi.org/10.1017/S1744137409990221

Rowley, J., \& Hartley, R. (2017). Organizing knowledge: An introduction to managing access to information. Routledge. https://doi.org/10.4324/9781315247519

Rueff, J. (1947). The fallacies of lord Keynes' general theory. The Quarterly Journal of Economics, 61(3), 343-367. https://doi.org/10.2307/1879560

Samuelson, P. A. (1951). Economics-an introductory analysis. New York, London and Toronto McGraw-Hill Book Company, Inc.

Sapir, J., (2010). La démondialisation. Paris: Seuil.

Scherer, F. M., Ross, D. (1990). Industrial market structure and economic performance. Houghton Mifflin Company.

Schreyögg, G., \& Kliesch - Eberl, M. (2007). How dynamic can organizational capabilities be? Towards a dual - process model of capability dynamization. Strategic Mmanagement Journal, 28(9), 913-933. https://doi.org/10.1002/smj.613

Schumpeter, J. (1934). The theory of economic development. Cambridge, MA: Harvard University Press.

Schumpeter, J. (1942). Capitalism, socialism and democracy. New York: Harper and Row.

Senge P. (1993). The fifth discipline: The art \& practice of the learning organization. London: Century Business.

Shackle, G. L. S. (1967). The years of high theory. Cambridge: Cambridge U.P

Silva, S. T., \& Teixeira, A. A. (2009). On the divergence of evolutionary research paths in the past 50 years: a comprehensive bibliometric account. Journal of Evolutionary Economics, 19(5), 605. https://doi.org/10.1007/s00191-008-0121-9

Simon, H. (1982). Models of bounded rationality. Cambridge, MA: The MIT Press.

Sollow, R. M. (1957). Technical change and the aggregate production function. The Review of Economics and Statistics, 312-320. https://doi.org/10.2307/1926047

Spilanis, I, \& Vlados, C. M. (1994). Development dynamics in Southern Europe. Studies in Regional \& Urban Planning, 3, 301-316.

Sraffa, P. (1926). The laws of returns under competitive conditions. The Economic Journal, 36(144), 535-550. https://doi.org/10.2307/2959866

Sweezy, P. M. (1946). John Maynard Keynes. Science \& Society, 398-405.

Tarondeau, J. C. (1999). Le management des savoirs et le renouveau de la pensée stratégique. Humanisme et Entreprise, (236), 97-115.

Veblen, T. (1898). Why is economics not an evolutionary science?. The Quarterly Journal of Economics, 12(4), 373-397. https://doi.org/10.2307/1882952 
Veblen, T. (1900). The preconceptions of economic science. The Quarterly Journal of Economics, 14(2), 240-269. https://doi.org/10.2307/1883770

Vernengo, M. (2010). Conversation or monologue? On advising heterodox economists. Journal of Post Keynesian Economics, 32(3), 389-396. https://doi.org/10.2753/PKE0160-3477320304

Vlados C. M. (1992a). Les dimensions technologiques dans la théorie de la régulation et la contribution de Coriat sur la conception analytique de la production de la technique et de la science. Diplôme d'Etudes Approfondies (D.E.A.). Séminaire de Recherche mineur sous la direction de B.Madeuf. Université de Paris X-Nanterre.

Vlados, C. M. (1992b). Politiques industrielles et stratégies des groupes multinationaux dans les secteurs de base-industrie des matériaux en Europe. Diplôme d'Etudes Approfondies (D.E.A.). Séminaire de Recherche majeure sous la direction de M. Delapierre (CEREM). Université de Paris X-Nanterre.

Vlados, C. M. (1996). International restructuring dynamics of competitive advantage. Middle East Forum, 1, 233-252. https://doi.org/10.2139/ssrn.3217975

Vlados, C. M. (2004). La dynamique du triangle stratégie, technologie et management: L' insertion des entreprises Grèques dans la globalisation. Thèse de doctorat de Sciences Économiques. Université de Paris X-Nanterre.

Vlados, C. M. (2005). The insertion of Greek firms into globalization: the dynamics of the triangle of strategy, technology and management. Tome of Proceedings of International Conference: Managing Global Trends and Challenges in a Turbulent Economy. University of the Aegean: Department of Business Administration.

Vlados, C. M. (2007). Development dynamics in South-Eastern Europe: The challenge of the new paradigm of cooperation, Middle East Forum, 6.

Vlados, C. M. (2012). The search of competitiveness and the entrepreneurial evolution in a global environment: Toward a new approach of development dynamics based on the case of Greek productive system. Journal of Management Sciences and Regional Development, 8. https://doi.org/10.2139/ssrn.3218008

Vlados, C. M., Deniozos, N., \& Chatzinikolaou, D. (2018a). Towards a new approach of local development under crisis conditions: Empowering the local business ecosystems in Greece, by adopting a new local development policy. International Journal of Regional Development, 5(1). https://doi.org/10.5296/ijrd.v5i1.11955

Vlados, C. M., Deniozos, N., \& Chatzinikolaou, D. (2018b). The "evil globalization" \& the central dialectic tug-of-war in the new globalization's shaping. Civitas Gentum, 6(1), 89-134.

Vlados, C. M., Deniozos, N., Chatzinikolaou, D., \& Demertzis, M. (2018a). Towards an evolutionary understanding of the current global socio-economic crisis and restructuring: From a conjunctural to a structural and evolutionary perspective. Research in World Economy, 9(1). https://doi.org/10.5430/rwe.v9n1p15 
Vlados, C. M., Deniozos, N., Chatzinikolaou, D., \& Demertzis, M. (2018b). Perceiving competitiveness under the restructuring process of globalization. International Journal of Business and Management, 13(8). https://doi.org/10.5539/ijbm.v13n8p135

Von Bertalanffy. L. (1973). Theorie generale des systemes. Paris: Ed Dunod.

Walras, L. (1874). Eléments d'économie politique pure ou théorie de la richesse sociale (Elements of Pure Economics, or the theory of social wealth). Lausanne, Paris.

Weinstein, O., \& Azoulay, N. (2000). Les compétences de la firme. Revue d'économie industrielle, 93(1), 117-154. https://doi.org/10.3406/rei.2000.3007

Weintraub, E. R. (2002). Neoclassical economics. In Henderson, D. R. (Ed.). Concise Encyclopedia of Economics (1st ed.). Library of Economics and Liberty.

Wenting, R. (2009). 6. The inheritance of organizational routines and the emergence of a firm genealogy in the fashion design industry. In Becker, M., \& Lazaric, N. (eds.). Organizational Routines: Advancing Empirical Research (pp. 103-128). Cheltenham: Edward Elgar. https://doi.org/10.4337/9781848447240.00012

Wernerfelt, B. (1984). A resource - based view of the firm. Strategic Management Journal, 5(2), 171-180. https://doi.org/10.1002/smj.4250050207

Wiener, N. (1948). Cybernetics or control and communication in the animal and the machine. John Wiley.

Williamson, O. (1991). Comparative economic organization: The analysis of discrete alternative. Administrative Science Quarterly, 36, 269-296. https://doi.org/10.2307/2393356

Williamson, O. (1999). Strategy research: Governance and competence perspectives. Strategic Management Journal, $20, \quad 1087-1108$. https://doi.org/10.1002/(SICI)1097-0266(199912)20:12\%3C1087::AID-SMJ71\%3E3.0.CO;2 $-\mathrm{Z}$

Williamson, O. (2000). The new institutional economics: Taking stock, looking ahead, Journal of Economic Literature, XXXVIII, 595-613.

Winter, S. G. (2006). Toward a neo-Schumpeterian theory of the firm. Industrial and Corporate Change, 15(1), 125-141. https://doi.org/10.1093/icc/dtj006

Witt, U. (2008). What is specific about evolutionary economics?. Journal of Evolutionary Economics, 18(5), 547-575. https://doi.org/10.1007/s00191-008-0107-7

\section{In Greek}

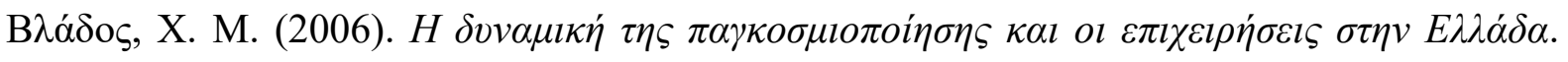

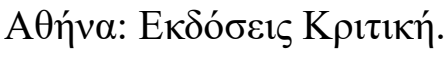

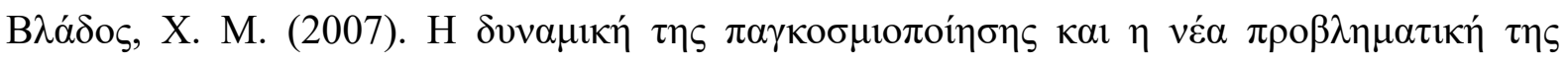

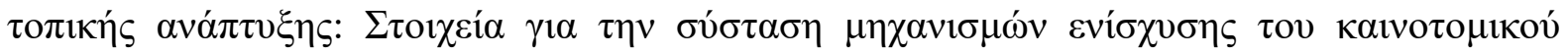

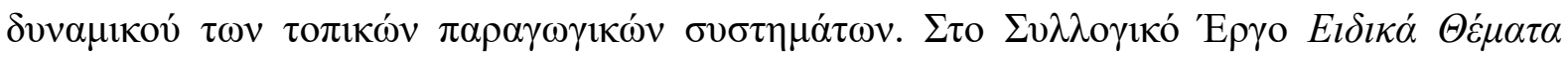




\section{Macrothink}

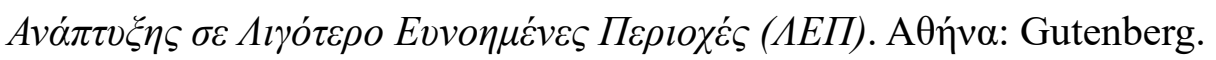

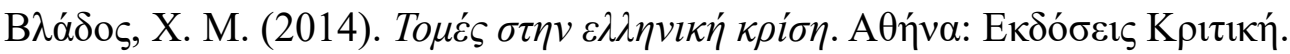

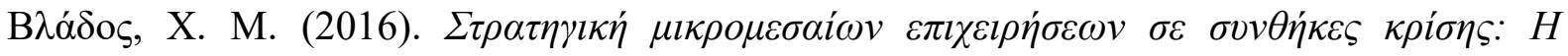

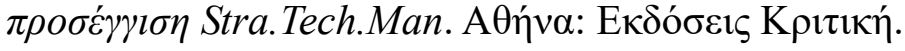

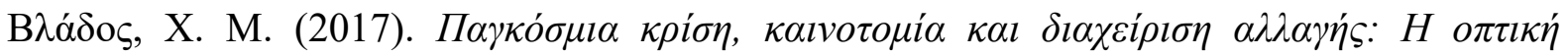

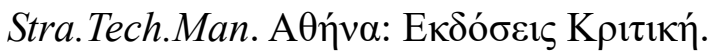

\section{Notes}

Note 1: However, this critique of the conventional neoclassical and Keynesian tradition does not imply that there is no important progress and evolution in these schools of thought nowadays. See, for example: (Vernengo, 2010; Weintraub, 2002).

Note 2: This scientific hypothesis was empirically tested (Vlados, 2004) for the Greek productive 'ecosystem'. It was proved, particularly, that the Greek economy has a peculiar 'fauna' of businesses (B $\lambda \alpha ́ \delta$ os, 2006).

\section{Copyright Disclaimer}

Copyright for this article is retained by the author(s), with first publication rights granted to the journal.

This is an open-access article distributed under the terms and conditions of the Creative Commons Attribution license (http://creativecommons.org/licenses/by/3.0/).

\section{Copyright Disclaimer}

Copyright for this article is retained by the author (s), with first publication rights granted to the journal.

This is an open-access article distributed under the terms and conditions of the Creative Commons Attribution license (http://creativecommons.org/licenses/by/3.0/). 